\title{
Aesthetic community
}

\author{
RUTH RONEN (iD) Tel Aviv University
}

ABSTRACT: Taste, as a faculty of aesthetic appreciation, involves an individual, and yet assumes a community. In this article, a distinctly singular mode of being attuned to objects of taste is shown to be conditioned by the consent of others and by being-with others, thereby constituting what is named here an 'aesthetic community.' This idea of an aesthetic community is traced back to Kant's sensus communis and to Heidegger's notion of preservation: for both, it is the presence of a community that conditions aesthetic experience.

RÉSUMÉ : Le goût, en tant que faculté d'appréciation esthétique, implique un individu, et pourtant suppose une communauté. Dans cet article, nous constatons qu'une disposition singulière à l'égard des objets de goût est conditionnée par le consentement d'autrui et par l'être-avec autrui. De cette façon, une communauté esthétique est établie. Cette idée de communauté esthétique remonte au sensus communis de Kant et à la notion de préservation de Heidegger : dans les deux cas, c'est la présence d'une communauté qui conditionne l'expérience esthétique.

Keywords: judgement of taste, aesthetic community, Kant, Heidegger, Nancy, sensus communis, preservation

\section{Consent to participate}

Edi Rama was elected mayor of the city of Tirana in 2000 (10 years after the downfall of the communist regime), a city in a state of decomposition, with

Dialogue 60 (2021), 319-336

(C) The Author(s), 2021. Published by Cambridge University Press on behalf of the Canadian Philosophical Association/Publié par Cambridge University Press au nom de l'Association canadienne de philosophie. This is an Open Access article, distributed under the terms of the Creative Commons Attribution licence (http://creativecommons.org/licenses/by/4.0/), which permits unrestricted re-use, distribution, and reproduction in any medium, provided the original work is properly cited.

doi:10.1017/S0012217321000093 
public areas widely dismantled or invaded, and in a chaotic political situation. Rama's first act was not to invest in roadbuilding or sanitation; rather, he utilized the municipality's meager funds (donated by the European community) to immediately enter a project of painting the facades of the city's buildings many of them dilapidated and deformed - with radiant colours. What may have seemed like an act carried out in bad taste, both politically and aesthetically, a cynical camouflage of decay in a city of despair and anarchy had a different vision behind it and brought about some unexpected consequences. ${ }^{1}$ The radiant colours painted over grey facades were shocking at first but then prompted vigorous debates among the city's people with regard to colour preference, even if many declared the colours to be distasteful. These debates gradually brought about change, and a marked transformation of the city. As the documentation of Rama's term in office recounts, the colours and the debates they aroused created a stir and a growing awareness of the surroundings. The colours brought change in the city inhabitants' involvement in the public sphere.

This story about Tirana brings to mind one of Immanuel Kant's curious suggestions regarding taste: in $\$ 22$ of the Critique of judgment, Kant asks whether taste should be regarded as acquired, or as an original and natural faculty. The answer depends on the place assigned to universal assent in employing this faculty: assent, the idea that one's judgement of taste has exemplary validity for everyone, is part of what taste ought to be. Universal assent reflects a demand of reason that one's taste converges with the taste of others, that our judgement is guided by such an ideal norm. Whether or not there is in fact such a common sense (i.e., a universal faculty), one ought to acquire taste so that it produces a "confluence of the feeling of everyone with that of each" (Kant, 1790/2000, §22, pp. 123-124). Whether such a demand for universal assent regulates all our judgements or only judgements of taste exceeds Kant's concern here, which is to generally validate a judgement (of taste) transcendentally unconditioned by interest, concept, or purpose.

The case of Tirana appears to exemplify this Kantian idea of taste as acquired thus inviting us to examine the relation of taste to the demand of a universal assent. Taste is exemplified here by a certain inclination, or attunement to matters of taste that one ought to develop. Having developed taste already equals the expectation that others would be in agreement, that there will be a confluence of the feeling of everyone with that of each. Tirana's 'aesthetic experiment' shows that the moment one is able to be attuned to sensible objects measures up to having a communal sense of others, as illustrated in the expectation that others have

1 These aspects of the project are discussed in an interview with Edi Rama (himself also an artist) and the artist Anri Salla at the Tate in 2009. Rama describes the circumstances that led him to conceive of this unorthodox line of action. Salla is the artist who made a film on this project and highlighted its intriguing aspects for art circles. 
acquired similar grounds for appreciating colours. The capacity to react to colours (or to objects of taste in general) hence amounts to entering a community of taste.

How does the appearance of taste as a relevant faculty already assume a demand of agreement? What is it about taste, a faculty of individual cognition, that involves others, that regulates the taste of others and their attunement to objects of taste ${ }^{2}$ ? The painting of buildings' facades in Tirana indicates that when recognizing a representation as an object of taste, this recognition functions as a call, an address made to others, to participate in an aesthetic experience, to likewise become attuned to sensible objects (colours). When the mayor sets off a call to experience things aesthetically, this call gains its force from a communality that ought to be at the core of such an experience. In other words, attunement to objects of taste, as a mark of having acquired taste, is equivalent to already participating in a community of taste.

Later in the Critique of judgment, Kant further associates the demand for the assent of others to beauty's moral standing, ${ }^{3}$ which can indicate the far-reaching significance of the 'ought' related to taste. But here my aim is to disentangle the preliminary relation Kant establishes between the acquisition of taste and the kind of communality it demands. Given the structural equation of taste with universal assent, an initial communal consent, understood as constitutive of the acquisition of taste, can explain how later, the colours brushed over buildings' facades became objects of aesthetic judgement and stirred vehement quarrels. ${ }^{4}$ Judging aesthetically means that taste, as communal faculty, had been acquired. Without a communal sense being part of the mere acquisition of taste, Rama's move would have stirred nothing, would have remained, indeed, an act in bad taste.

The example of Tirana exposes a preliminary moment of communal consent associated with one's acquisition of taste. This communal quality is the condition for the ensuing judgements of taste, as for conflicts of taste (i.e., quarrel over colours), and for civil action (i.e., rehabilitation of city life). The consent to appreciate objects of taste, which for Kant equals a duty, is isolated in this case as what was sparked prior both to an actual enactment of the faculty of

2 'Attunement' refers to Stimmung in the German, translated as 'disposition' by Paul Guyer (the translation used in this paper) and as 'attunement' by Werner S. Pluhar in Kant's other canonical translation. I prefer this latter translation in the present context as it suits better the idea of taste as acquired faculty.

3 "Now I say that the beautiful is the symbol of the morally good, and also that only in this respect ... does it please with a claim to the assent of everyone else ..." (Kant, $1790 / 2000, \S 59$, p. 227).

4 As in Kant's solution to the antinomy of taste where quarrel (a laying claim to other people's assent to judgement) is opposed to dispute (decision by means of proof). Kant, $1790 / 2000, \S 56$, p. 211. The quarrel over colours is hence a symptom of being involved in an aesthetic judgement. 
taste and prior to public action. In this article, I explore the nature of this prior consent to become engaged with an aesthetic object, and to establish the sense in which this consent is communal.

When Pontius Pilatus stares at the observer beyond the canvas in Caravaggio's Ecce homo, or when Pina Bausch's dancers walk into the hall to serve tea to the audience (in Tanztheater Wuppertal Pina Bausch, 1980), or when the sound of Bach's $5^{\text {th }}$ cello suite is heard from a neighbour's window, the observer or listener is called to participate in the work of art. As in the case of Tirana's painted facades, these artistic gestures can be regarded as a preliminary summoning of an addressee, whomever is willing to attend. But how can the communality that inheres in these gestures of soliciting taste be qualified? These gestures call for a universal assent that does not hinge on any specific subject of taste, nor on any definite quality of the object of taste (whether it be art, nature's beauty, or any accidental image met with). Further, the consent to be attuned to an object of taste does not assume a felicitous aesthetic judgement; being attuned to an object of taste may, for instance, end up with the faculties failing to assess its aesthetic merit.

But most importantly, the consent called for acknowledges unspecific others, anyone attuned to the object of taste. Pilatus' stare is addressed to anyone standing in front of the painting, returning a gaze, and the sound of Bach's suite infiltrates, through the mixture of city sounds, the ears of whomever wishes to listen. $^{5}$ An individual consent (equivalent to Kant's acquisition of taste) to be engaged with an object of taste implies that this object is expected to be likewise viewed, heard, and aesthetically appreciated by whomever. Summoning one's faculty of taste is an address in the plural, an address to whomever singular listener or observer who will answer the call: 'Come and listen/look!'

The idea that aesthetic appreciation involves others is fundamental to Kant's aesthetic and to his theory of the faculty of taste, as suggested by notions such as: sensus communis, universal assent, and universal communicability. I will examine in later sections of this article the way Kant and Martin Heidegger position others as part of the (aesthetic) encounter (experience) with art (beauty), ${ }^{6}$ and further establish the idea that communal consent conditions aesthetic experience. I will suggest that a preliminary communal consent on the part of the

5 See a similar idea in Jacques Lacan's description of a person before a picture: "You want to see? Well, take a look at this! He gives something for the eye to feed on, but he invites the person to whom this picture is presented to lay down his gaze there as one lays down one's weapons" (Lacan, 1973/1977, p. 101).

6 Heidegger opposes the aesthetic tradition on various counts, yet for present purposes I will refer to aesthetic experience as a general name for both Kant's aesthetic theory and Heidegger's analysis of the mode of Dasein's being-with artworks. The divergence of their views will be brought up only when it becomes consequential for the argument unfolded here. 
beholder/listener, a consent acknowledging that taste, having been acquired, affirms the necessity of others. Before turning to examine the place of communal ideas in aesthetic theory, in this section, the question of who are these others, whomever is willing to attend and who constitute an artwork's aesthetic community, is examined. In what follows, I will attempt to qualify aesthetic communality (to distinguish it from other ways of affirming the necessity of others). I will then move to consider the roots of such a notion of aesthetic community in the aesthetics of Kant and in Heidegger's work on "The origin of the work of art." Overall, my argument is threefold: that the assessment/judgement of artworks includes a preliminary consent; that this consent is communal; and that this communal consent is aesthetic. In sum, I suggest that aesthetic judgement is conditioned by a specifically aesthetic consent to being-with (be attuned to) artworks and that this consent is communal.

\section{Which community?}

The notion of community can mean many things and serve many purposes (Bell, 2020). It can relate to the positioning of the individual within a social link based on contingent attachments or on one's sense of identity, it can serve diverse political interests (to advance solidarity, equality, or rights), and it can be used to disregard conflicts or to exhibit them. Here, I concentrate on the preliminary notion of a community as what affirms the presence of others and do not enter into more general issues regarding communities and their social role. So, prior to the political consequences of Rama's act toward creating urban life for Tirana's inhabitants, the city's people were engaged with aesthetic objects. This aesthetic engagement reflects a preliminary consent to be attuned to objects, hitherto unheeded, a consent that already assumes that others are necessary for the appraisal of such objects (of taste). How can 'terms of communality' be defined, or how are others qualified as necessary constituents of such an engagement?

An aesthetic object is addressed to anyone ready to engage in an experience of taste, and anyone who consents to participate (who acquires taste, in Kant's terms) does not hold prior knowledge regarding the appropriate appreciation of the object. This qualification of taste as dissociated from prior knowledge, reveals that the terms of participating in an aesthetic community differ from those of a political one; the latter assumes a shared understanding of a given situation, of its anticipated outcomes, and of definite concepts or aims that guide the community (hoped-for values, ideologies, etc.), as part of the affirmation of others. The first striking thing about Tirana is that no definite concepts can afford an understanding of the situation to which the painting of facades relates, nor can one assume a shared understanding of the given state of affairs. An aesthetic community is simply established on the expectation of a universal agreement that others will also answer the call of taste, rather than on shared concepts or beliefs. 
The consent to participate in an aesthetic experience highlights another important aspect of aesthetic communality. Counter to what may appear to be the minimal demand required for establishing a community, aesthetic communities do not overcome singularities. The colourful facades of Tirana are directed to the singularity of whoever agrees to participate. From this, it can be surmised that, while the aesthetic community is not a community of specifically qualified individuals, participation yet depends on the singularity of taste. An aesthetic community is a plurality constituted by singular attunement (rather than by a collective one). In other words, taste as a vehicle for communality does not transform individuals by way of a universal standard ${ }^{7}$; it does not depend on the overcoming of differences. Aesthetic communal consent affirms the necessity of others as singular beings with singular tastes.

Such terms of communal consent, acknowledging others as singularities, stand in opposition to the transformative power habitually ascribed to communities. For Jean-Jacques Rousseau, for instance, the social contract is constituted where each individual "places in common his person and all his power under the supreme direction of the general will; and as one body we all receive each member as an indivisible part of the whole" (Rousseau, 1762/1947, p. 15). Rousseau established the idea of the individual who delivers herself entirely to the community, which means that - for a community to be established — the individual is transformed into a community associate, that is, she turns into a social being. Unlike this understanding of individual interest (and will) transformed into a communal one, in the case of aesthetic community, singularity is not given over to the community but rather, the community is sustained by singularities.

The second striking thing about the Tirana case is that participation in the debate over colours does not assume a shared interest (even if it can lead to one). The community of art stands, in this sense, at the opposite end from the community of Rousseau, which assumes that "it is what is common in these different interests that forms the social bond; and if there was not some point in which they all unanimously centered, no society could exist" (Rousseau, $1762 / 1947$, p. 23). Unlike Rousseau's idea of the social bond, singular individuals participate in the community of art without (yet) having a common interest.

A judgement of taste hence affirms the necessity of others unqualified by any definite knowledge, holding no particular qualities (of sensitivity or knowledge), and sharing no specific interest or idea in common. The aesthetic community is further non-transformative with regards to the singularity of the observer/

7 Note that for Kant, universal agreement or common sense depends on the understanding that the cognitive faculties employed in any judgement are the same in everyone, but as Henry Allison notes, this in itself explains why judgement in general demands agreement but does not yet explain a specific sensus communis aestheticus (Allison, 2001). As said before, sensus communis aestheticus, that is, what is aesthetic about universal assent, is its necessary partaking in the acquisition of taste. 
listener. These elements will be further developed in what follows as the marks of an aesthetic community.

\section{A community of singularities}

In this article, I suggest that aesthetic communities invite a reconsideration of the relation of a community to the singularity of its members. The idea that aesthetic communities are constituted by what is singular rather than by what is common or shared, stems from the particularity of taste, a faculty that cannot be acquired unless regulated by communality. In general, the path for thinking communality in singular terms is offered in Jean-Luc Nancy's study of the singular plural where singularity is presented as a fundamental form of being-with (Nancy, 1996/2000). A community as a mode of singular being-with is a community in which singularity is not absorbed nor assimilated. Being-with can hence be opposed to the idea of a community as a group of individuals sharing or participating in a common thing, like a common desire to be satisfied, a shared element (like a leader or a trait) or a common need, a shared ideal, interest, or norm. In such a view, a community is sustained by what is actually shared (i.e., a geographical place), by what is grasped as an end to be attained (i.e., the common good), or by what is postulated as an ideal (i.e., freedom in G. W. F. Hegel's civil society).

A community formed in terms of what its members share, whether as a higher form or substance or as common interest or aim, entails segregation. From the community of poetry-lovers or that of the trans-sexual gender to the school of analytic philosophers, Smokers Anonymous, and the Ku Klux Klan - a community based on sharing, abstaining from or rejecting a common thing (practice, idea, or interest) would not be a community if it did not mark those excluded from it by force of what they lack, with regard to what the community has in common. A community's common ground gives rise to questions regarding difference, among its members and in relation to those outside the community. The necessary presence of difference (from external others) in the constitution of communities is the other side of indifference (equal footing, equal rights) within the community: the establishment of communities indeed gives rise to various modes of fighting for or demanding equality (of rights, of opportunities) for members of a given community; overcoming difference is taken to condition membership in a community.

Difference and indifference miss what is unique in an aesthetic community, a community that is conditional on singular assent to participate in a judgement of taste (prior to shared concerns). Singular consent does not depend on an atomistic understanding of the aesthetic community (as composed of individuals indifferent to others), but is rather a community constituted by singular consent to be-with others equally attuned to objects of taste. Common sense, as will be shown below, does not refer to sense in common, in the plural. Singular consent as a vehicle of communality does not rely on a shared interest, nor on a definite difference of community members from other, 'taste-less' individuals. 
How can a singular consent constitute a community? For Kant, as will be shown in the next section, in judging, one relies on the fact that "In all human beings, the subjective conditions of this faculty [of taste], as far as the relation of the cognitive powers therein set into action to a cognition in general is concerned, are the same, which must be true, since otherwise human beings could not communicate their representations and even cognition itself' (Kant, 1790/ 2000 , remark to $\S 38$, p. 170). To be universally communicable, judgement must involve the same faculties in all appreciators, so how can singular consent be considered as communal without positively counting on shared faculties?

As part of his extensive writings on the community and on beingin-the-plural, Nancy proposes the concept of a community of finitude. This notion of community assumes neither a higher substance nor a universal quality to ground communality. Nancy notes that binding the community to any transcendental substance runs counter to the political way of life as originally understood by the Greeks: life as a being-in-common. "Being in common means ... no longer having, in any form, in any empirical or ideal place, such a substantial identity, and sharing this (narcissistic) 'lack of identity' ... community is made or is formed by the retreat or by the subtraction of something: this something, which would be the fulfilled infinite identity of community ..." (Nancy, 1986/1991, pp. xxxviii-xxxix). A community that assumes being-in-common (rather than a common being) is a community from which common identity is subtracted. Within such a picture, singularities (rather than individuals who are delimited from others) form a community where the finite singularity is without form or ground (Nancy, 1986/1991, pp. 26-27). It is a singularity that is neither extracted, nor produced, nor derived, a being-with others "before the judgment of community as law" (Nancy, 1986/1991, p. 28). Nancy refers to terms of communality, which are constituted by the very structure of singularity.

The issues raised by Nancy regarding the relation of the singular being to the political community (the community as law) are numerous. But here, I examine the tip of this complexity: the retrieval of the Greek notion of being-in-common as key to understanding communities can illuminate the notion of aesthetic community as constituted by a preliminary mode of singular consent 'without form or ground.' A community of finitude is a community of singularities resisting ideals and qualities that would decide the place of the individual in common life. Such ideals and qualities have traditionally alienated the singular being from the community (e.g., the individual is never up to the ideal or, cannot be completely disengaged from personal interests or desires). Alienation is the result not only of attempts to integrate the individual into the essence of society by eradicating singular proclivities, but also of the fact that "the question of community is so markedly absent from the metaphysics of the subject, that is to say, from the metaphysics of the absolute for-itself ..."; it is a metaphysics "without relation" (Nancy, 1986/1991, p. 4). That is, communities alienate the subject either by subjugating singularity or by considering the essence of subjectivity as absolutely singular (i.e., lacking an originary sense of sociality) and hence 
imposing an irreducible hiatus between singular life and communal life. The community of finitude is a community of real singularities (rather than of transcendental egos), who do not dissolve into the community and yet their participation in life in-common is originary. Collective life, being-in-common, is not an alternative value to singularity, but coexistent with "being self" (Nancy, 1986/1991, p. xxxvii).

Participation in a community eludes any common ground since the only thing all individuals face in common is death, says Nancy, and death cannot be integrated into singular being, nor can it be made immanent to collective being. A community with no ground in common, which does not alienate the singularity of being, also lies outside the differential support of segregation, outside the "delirium of an incarnated communion" (Nancy, 1986/1991, p. 35). It is community given to us "in advance of our projects, desires, and undertakings," a community that cannot be lost or ungiven (Nancy, 1986/1991, p. 35). A community of finitude emerges at the place of the singular being, and as an instigator of singularity. In what follows, this 'community of finitude,' the idea of singularity as initiated through the affirmation of others, will be used in order to ground aesthetic experience in an initiatory moment of such a consent to being-in-common.

\section{Being-in-common with an aesthetic object}

In this section, I trace notions of communality as they appear in aesthetic thought, showing that the encounter with beauty or with art is necessarily communal and that the community is intrinsic to one's singular engagement with objects of taste. Specifically, in the work of Kant and Heidegger, one can find a common motive that highlights engagement with beauty (in Kant) or with works of art (in Heidegger), as a communal experience.

The association of artforms with communal participation has been present throughout the history of thought — from Plato and Aristotle, ${ }^{8}$ who associate art with modes of participation in the public domain, to Kant's aesthetic theory where a universal assent distinguishes aesthetic judgements and grants them their validity, to contemporary notions such as Jacques Rancière's aesthetic regime (Rancière, 2000/2006), where the appreciation of art is conditioned by a culture of sense. I will first look into the notion of communality developed in aesthetic theory, before reaching the final point of showing how these notions condition the very encounter with art, or with objects of taste.

“... (T)hrough the judgment of taste (on the beautiful), one ascribes the satisfaction in an object to everyone ..." (Kant, 1790/2000, pp. 99-100). In her Lectures on Kant's political philosophy, Hannah Arendt foregrounds the

8 For instance, Aristotle's discussion in the Politics of the role of music for social life in the Polis (Pol. 8.7, 1341b), or Plato's Symposium where the love of beauty cannot appear outside the exchange of the interlocutors who deeply disagree. 
communal dimension in the Kantian notion of judgement: for Kant, the faculty of judgement presupposes the presence of others, and "one judges always as a member of a community, guided by one's community sense," Arendt says (1977/1992, p. 75). The presence of others is presupposed in aesthetic judgements for a number of reasons. First, just as critical thinking, which is in principle a solitary business, cannot be cut off from the standpoints of others (it is brought to bear on the thinking act by way of imagination), so a judgement of taste, which is always a singular act, constantly inspects others' standpoints and their tastes. Second, judgements of taste involve representations, which are already distant from mere objects of sensation; representations hence involve disinterested evaluation, they belong to an order of perception where others' judgements are taken into consideration (Arendt, 1977/1992, pp. 67-68). For Kant, so Arendt claims, the critic and the spectator (and not the actor and the maker), those who can see the whole, who constitute in their act the distance suitable for judgement, exemplify aesthetic judgement (Arendt, 1977/1992, p. 55). Third, aesthetic judgement releases us from our private circumstances, which can explain how taste can be communicated to others (for Arendt, this communal sense conditioning our very faculty of judgement is revealed in Kant's theory of taste). Lastly, Arendt also explains the communality of judgement in terms of the public sphere: to be implemented, a judgement of taste "always reflects upon others and their taste, takes their possible judgments into account. This is necessary because I am human and cannot live outside the company of men. I judge as a member of this community and not as a member of a supersensible world ...." (Arendt, 1977/1992, p. 67). ${ }^{9}$

Arendt equates aesthetic appreciation with the distancing of the subject from singular or immediate involvement, and with considerations of the actual practice of judging objects of taste in the public domain. ${ }^{10}$ Here, with Arendt, the place of a communal sense as part of the singularity of being is stressed, since Arendt's main thesis is that, in Kant, the very structure of judgement is already communal.

Having assessed the notion of a community of singularities (with Nancy) and of the communality of judgement (with Arendt), I can now return to investigate

9 Arendt associates her understanding of the communal dimension in aesthetic judgements with Kant's more general philosophy, which puts every type of action to the test of publicity. Public consent is also a condition of morality: in Kant's understanding of practical reason, when one wishes to discern the appropriate action for one's moral pursuits, the test is that of generality, of general consent. Only an imperative that can be generally applied is a moral one. The same validity of a moral action based on general consent also applies to the work of art.

In this sense, Rancière, with his idea of an aesthetic regime, follows the line established by Arendt in positing a community of sense, as a standard imposed on the singular being by way of a political press. 
taste and its communal underpinning in aesthetic theory. According to Kant, beauty is made an object of aesthetic judgement via two of our capacities: (1) imagination, that is, the ability to make an object present by way of representations (Vorstellungen); and (2) the sensus communis, which universally validates one's faculties of judgement from subjective grounds. Sensus communis, reasonably taken as a regulative principle, means that, in judging aesthetically, it is assumed that cognitive conditions (like purposiveness, conformity of a representation to a rule, etc.) are operative in one's judgement, and are operative in others.

But even before Kant considers the function of sensus communis with regard to the overall operation of judgement (as part of the deduction), it already appears in Kant's section on "the analytic of the beautiful" as what Henry Allison describes as a kind of supreme condition from which other moments of the analytic can be deduced. ${ }^{11}$ Everyone ought to assent to an aesthetic judgement and "one solicits assent from everyone else because one has a ground for it that is common to all" (Kant, 1790/2000, §19, pp. 121-122). Kant asserts that a judgement of taste requires the assent of everyone to gain its validity: “... as a necessity that is thought in an aesthetic judgment, it can only be called exemplary, i.e., a necessity of the assent of all to a judgment that is regarded as an example of a universal rule that one cannot produce" (Kant, 1790/2000, §18, p. 121). A pure judgement of taste, albeit subjective (connected to feeling), is exemplary, that is, it assumes the agreement of others to the correct assignment of a universal rule to a representation.

Commentators on Kant's Critique of judgment disagree over the correct way to interpret the relations between the first three moments and the fourth one (which posits the modality of a judgement of taste as necessarily pleasing). Here, I follow the outlines of Allison's commentary, in order to assess the preliminary place of a communal sense within the structure of a judgement of taste. The demand for agreement, claims Kant, presupposes the idea of sensus communis, and Allison unfolds in his commentary the idea that sensus communis conditions the very possibility of judging aesthetically (and hence subsumes the other three moments). While the other moments exhaust the content of judgements (as being disinterested, based on free harmony of the faculties, and related to the form of the object of representation), the demand for agreement, in orienting judgements of taste from subjective terms to common sense, is "postulating a capacity that is a necessary condition of taste, understood as a sensus communis aestheticus" (Allison, 2001, p. 155). That is, common sense conditions aesthetic judgement by indicating that the judgement is what it ought to be: based on the assent of others. This 'ought to be' relates to the specifically aesthetic conditions of judgement since here attunement to a representation follows a

11 The idea of a common sense is "an idea which combines within itself all of the factors analyzed separately" (Allison, 2001, p. 144). 
rule that cannot be stated. Sensus communis aestheticus amounts to a "correct subsumption of the instance (the particular appraisal) under the unstatable rule" (Allison, 2001, pp. 147-148).

Allison's reading of Kant hence allows us to identify aesthetic common sense as a prior condition of judgements of taste. Aesthetic common sense grounds the capacity for immediately seeing through feeling whether and how fully a given intuited manifold accords with a particular judgement. ${ }^{12}$ Common sense compensates for the lack of common knowledge (i.e., a universal statable rule) or of a distinct shared sensation ${ }^{13}$ in judgements of taste.

When Kant refers to the sensus communis to justify the general applicability of reflective judgements, it is presented as regulative with regard to human cognition, rather than as a law shared or commonly known. Common sense is the idea of reason that accounts for the assent of others in every judgement: the subject of aesthetic judgements is "holding his judgment up not so much to the actual as to the merely possible judgments of others, and putting himself into the position of everyone else, merely by abstracting from the limitations that contingently attach to our own judging” (Kant, 1790/2000, §40, p. 174). The ability to place ourselves in the position of others is hence equivalent to what initially defines an aesthetic judgement: it is a judgement that demands the giving up of whatever threatens to contaminate our judgement with elements of personal taste and predilection (charm or emotion), and the relinquishing of concepts (which would turn the judgement into a determining judgement of understanding).

It is here that the singularity of the subject in the aesthetic scene appears as neither individuated nor universalized; this subject draws the correctness of judgement by proclaiming its applicability to all (based on an unstatable rule).

Common sense introduces an indeterminate standard of taste (i.e., a standard that cannot rely on one's knowledge of universal rules) as having exemplary validity: others — whoever is similarly attuned toward beauty — are expected to consent to one's judgement as part of an original and natural ability to make a judgement of taste. A judgement of taste does not seek consent but assumes "the idea of a communal sense, i.e., a faculty for judging that in its reflection takes account (a priori) of everyone else's way of representing in thought, in order as it were to hold this judgment up to human reason as a whole ..." (Kant, 1790/ $2000, \S 40,173)$. Aesthetic experience demands a communal sense as part of our

12 'For without the 'peculiar talent' to recognize a fit between imagination and understanding under the conditions of cognition, a capacity to do so when the faculties are in free play would remain a completely inexplicable mystery" (Allison, 2001, p. 155).

13 For Kant, pleasure in beauty is not a distinct kind of pleasure: what makes pleasure distinctly aesthetic is its being part of the cognitive arrangement in which it participates (Kant, 1790/2000, §9, p. 102ff.). 
belief that our judgement of taste is a valid reflection of our human faculties. Putting ourselves a priori in the position of others is what ensures the valid pursuit of taste.

There is a common thread leading from Kant's sensus communis to the preservation that Heidegger assigned to Dasein, whenever Dasein attends to an artwork. A similar structure of singular participation that involves other appreciators resonates in both contexts, traversing these two ends of aesthetics: Kant as the herald of aesthetic theory at one end, and Heidegger as the ultimate underminer of aesthetic thought at the other. Even if with Kant and Heidegger two very different understandings of the order in which one participates in art are present (grosso modo: the difference between an a priori ideal order and an order of being-with as actual possibility), both thinkers describe the encounter with art in terms of a plurality, which advocates a sense of communality that this article aims to unearth.

Turning to Heidegger, one encounters the idea of preservation (die Bewahrung) setting up what can be termed a community of art guardians: "Just as a work cannot be without being created but is essentially in need of creators, so what is created cannot itself come into being without those who preserve it" (Heidegger, 1950/1971, p. 46). Preservation is part of a preliminary act that brings art into being by giving presence to its world. The artwork as given is opaque and closed to us, says Heidegger, and to be disclosed, it is in need of its preservers (die Bewahrenden). These are the preservers on whom hinges the weight of truth that an artwork discloses.

The work of art is created by an artist, but it is not the artist alone who constitutes the origin of the artwork: "The work makes public something other than itself" (Heidegger, 1950/1971, p. 19), something other than its thingness and its mode of creation; that is, the artwork is an event of a truth that must be brought forth. In order for the artwork to disclose truth, which in "The origin of the work of art" is identified with disclosing the work's world (Young, 2001, p. 22), a world which, by its very creation, is destined to decay and perish, this world must be preserved.

What is this 'world' that must be preserved? Heidegger had diverse and changing ideas about Dasein's relation to its environment and to the world, to other people, and to the composite ensemble of Dasein's being-in-the world. One important sense of 'world' appears in Being and time in relation to Mitsein, to being-with others, which is a fundamental condition of one's being in the world. Another fundamental condition associated with 'world' is related to (wo)man being world-forming (as opposed to the stone, which is worldless). ${ }^{14}$ Preservation highlights a world-forming dimension in the artwork that goes beyond Dasein's being in a world and being-with-others. What makes

14 “... man is not merely a part of the world .... Man has world ... [M] an is worldforming.” Heidegger, 1983/1995, pp. 176-167. 
the artwork world-forming is not just the world-creating activity of an artist, but the world-disclosing act of a preserver. Preservation assumes being-with the artwork as world-forming, since this world is not given but must be brought into presence.

Preservation counters the immanent world-withdrawal of every work of art and hence conditions the opening up of the world of the artwork as a happening of truth (as in Heidegger, 1950/1971, p. 56). As much as creation brings art into being, there is no creation without preservation: the artwork — whether a sculpture made in stone, a musical piece made of sounds, or a painting made of colours — does not become visible or audible without this prior position of being attuned to the world of the work, that is, to preservation. To face art, one must come under the power of the work, "stand within the openness of beings that happens in the work" (Heidegger, 1950/1971, p. 65).

But in what sense is preservation a communal intervention? Heidegger objected to the idea of a common world, to the 'they' who dictate how the world is, what it signifies, a world produced and held by the common view. The preservation related to the artwork suggests a world that is independent of the 'they' in its prevailing ${ }^{15}$; it is not a world that is always already given. Heidegger is concerned with the very fundamental being-with that the art-world demands of Dasein. Art needs its preservers to disclose the truth of a world that is not one's own, to go out of the world of the 'they' in order to turn a reticent, opaque work into a happening of truth:

If a work does not find preservers, does not at once find them such as respond to the truth happening in the work, this does not at all mean that the work may also be a work without preservers. Being a work, it always remains tied to preservers, even and particularly when it is still only waiting for preservers ... to enter into its truth. (Heidegger, 1950/1971, pp. 64-65)

With the preservers, Heidegger assumes Dasein's necessary involvement with the world of others, with the artwork's world (the world of the ancient believers in the Greek temple, the world of the farmer treading the fields). As reader or spectator, one is not just in-a-world, but is committed to the world of the work, because the work of art, to be art, is in need of a preserver to open up its world and keep it in force. Such is the sense in which preservation is a communal standing in relation to the artwork.

Preservation is a mode of being-with art rather than an activity of some kind. It is not an act on something, nor does it involve active involvement, and yet it is an answer to a demand, to a call to be part of the world of others. It is as if the truth of the artwork is deposited with its preservers, that the creation of an

15 "Prevail" (walten) is one verb associated with a world to suggest its being as world (Heidegger, 1983/1995, p. 360). 
artwork assumes the consent of those to whom the artwork is entrusted, those who can disclose its truth, to take part in world-forming. Preservation, then, goes beyond the mere being-in-the-world of Dasein, since it tells us something more far-reaching about being-in-common-with the work of art. War and peace or The red and the black are artworks withholding the history of a people, bringing to presence a world whose significance extends beyond the novel and its immediate reader. Hence, in reading these novels, as much as in observing an ancient Greek temple, what has disappeared of the world of the work reappears and comes forth. And yet, a world is not a common object and preservation is needed precisely because the world of the farmer, while it is opened up, at the same time remains closed, lost for us. This is the particular mode of beingwith the artwork exemplified by preservation: it cannot rely on shared knowledge nor does it reproduce lost meaning to be shared.

But preservation assumes a further point: it brings forth a world (of the historical moment it withholds) by counteracting the withdrawal of the world into opaque materiality. Preserving the Greek temple means that the material of the work does not disappear: "the rock [on which the temple stands] comes to bear and rest and so first becomes rock; metals come to glitter and shimmer, colors to glow, tones to sing, the word to speak. All this comes forth as the work sets itself back into the massiveness and heaviness of stone, into the firmness and pliancy of wood ..." (Heidegger, 1950/1971, p. 45). Preservation means being-in-common with the way a world prevails, which means disclosing the truth of its materiality (which was vividly real for its original people) without reducing the artwork to mere material. Preservation transgresses the distance between the partial picture of a farmer's world and the singular sensation of which the work, as a material thing, makes use. This is what being-in-common with a world means.

For Heidegger, then, the work of art, which sets up a world, assumes preservers who make this world speak to us, through its material presence. These two dimensions of the artwork - that it opens up a world, and that this world needs to be made present, disclosed by preservers - relate to the following observations regarding the way preservation attains its aim:

1. Due to the structure of truth Heidegger assumes (i.e., a rift between world and earth), the world of the work, forgotten and decayed, cannot be fully restituted but only known to the extent that it needs to be unconcealed.

2. Preservation is not an act but a mode of attunement toward the work of art: "... letting of the work be a work ... present in the manner of a work" (Heidegger, 1950/1971, p. 64).

Preservation is hence a mode of being-with the artwork, a "standing-within ... the truth that is happening in the work" (Heidegger, 1950/1971, p. 65), which manifests a future moment, a moment where the world of the work is disclosed. 
Without going into the special temporality assumed with this idea of setting forth a world, of the artwork being ahead of itself, it can be said that preservation is a position of expectation regarding what an artwork demands. It is the disclosure of the artwork's world (rather than of a world as a common object) in excess of its creation (since the world of the work is a world of the past, a world disclosed as lost). Preservation is a mode of being toward the artwork prior to disclosure; without preservation, the artwork is either void or given to "aestheticizing connoisseurship" (Heidegger, 1950/1971, p. 66). In other words, preservation is not one among possible orientations toward the artwork, but a condition of the very possibility of art to be considered a happening of truth.

Heidegger criticized Kant for the idealized foundations of his aesthetics. And yet, the preservation assumed by Heidegger appears to address the same problem of immanent closure that beauty imposes and that Kant addresses with sensus communis. If, for Heidegger, the work of art needs disclosure, for Kant, the subjective circularity of sensation needs to be restricted in order for aesthetic judgement to present a valid epistemic pursuit. Furthermore, for both thinkers, communality is inscribed as a condition of our encounter/experience of art, which is yet posited as a future moment (of others' consent to judgement, or the future disclosure of the artwork's world). Thus, it appears that Kant and Heidegger both assume, albeit in different terms, an idea of communality as a mode of consent to be attuned to art/beauty.

The aesthetic community is a community of whomever: "Whomever [quelconque] is the thing together with all its properties; none of which, however, constitutes difference. The indifference toward properties is what individualizes and disseminates singularities..."16 The idea of a community composed of singularities indifferent to their differential qualities, a community of whomever, as proposed in various terms by Giorgio Agamben and Nancy, has served us to develop a parallel idea of an aesthetic community. A community of singularities is a necessary factor in one's consent to be attuned to the work of art or to experience beauty.

The aesthetic community is presented here as a condition of the structure of judgement (in Kant) and on Dasein's being with art (in Heidegger). Hence, communality involves a consent not necessarily attained or even attainable, but rather a consent necessarily posited for the encounter with beauty or art to

16 Agamben, 1990, p. 25, my translation. In this book, Agamben dwells on the idea that a community is not composed of individuals who share particular properties, nor is it formed on the basis of a general or collective mode of being. The perfectly common lies in exemplary singularity that does not refer to any essence, that does not stand as an example for anything. A community would therefore be the place of whatever singularities. 
occur. Robinson Crusoe decorated his cabin on a desert island because beauty is communal even when there is nobody around.

Kant's aesthetics and Heidegger's philosophy of art introduce the idea that beauty and art depend on a demand to participate (in-common) being answered. This answer (which Kant calls "agreement" and Heidegger terms "preservation") does not need a delirium of togetherness or of oneness to be sustained: "The community that becomes a single thing (body, mind, fatherland, Leader ...) necessarily loses the in of being-in-common. Or, it loses the with or the together that defines it. It yields its being-together to a being of togetherness. The truth of community, on the contrary, resides in the retreat of such a being" (Nancy, 1986/ 1991, p. xxxix). The aesthetic community is hence made present at the moment when, being-alone, we lend our ear to the sounds of a cello infiltrating our space from a neighbour's apartment. The sound reaching our ear is the sound of our being-in-common with the work of art.

\section{Conclusion}

The work of art occupies a place in the public domain, Arendt claims, and like the French Revolution, its importance in the history of humankind is owed to the enthusiastic participation of its onlookers, "the exaltation [of] the uninvolved public' looking on in sympathy without the least intention of assisting" (Arendt, 1977/1992, p. 61). While Arendt uses communal sense (and assent) in Kant to situate art in the political domain, she illuminates an important aspect of participation: the onlooker, even if she does not hold a particular worldview or share the opinions of the revolutionaries, is part of what constitutes a historical event and grants it its collective importance. The onlooker is not a passive agent but, rather, any singular being who commits to the events and thereby assigns them their future impact. Likewise, the event of beauty (and art) is dependent on its onlookers and on their singular consent to participate in an aesthetic experience, to disclose its truth. The participation of others is constitutive of the very structure of the aesthetic experience. Hence, in returning the gaze of Pontius Pilatus in Caravaggio's painting, this onlooker turns into a participant in an event of art; this look in return, discloses a consent to be attuned with others in a similar position, as part of what experiencing the painting entails. It is this being-in-common with art that explains why the community of art is necessarily a community of no one in particular, and yet composed of singularities fully committed to art.

\section{References}

Agamben, G. (1990). La communauté qui vient : Théorie de la singularité quelconque, trans. M. Raiola. Éditions du Seuil.

Allison, H. E. (2001). Kant's theory of taste: A reading of the critique of aesthetic judgment. Cambridge University Press.

Arendt, H. (1992). Lectures on Kant's political philosophy. University of Chicago Press.

(Original work published 1977.) 
Bell, D. (2020). Communitarianism. In E. N. Zalta (Ed.), The Stanford encyclopedia of philosophy. https://plato.stanford.edu/archives/sum2020/entries/communitarianism/

Heidegger, M. (1971). The origin of the work of art. In Poetry, language, thought (pp. 15-87). Perennial Classics. (Original work published 1950.)

Heidegger, M. (1995). The fundamental concepts of metaphysics: World, finitude, solitude. Indiana University Press. (Original work published 1983.)

Kant, I. (2000). The critique of the power of judgment. Cambridge University Press. (Original work published 1790.)

Lacan, J. (1977). The four fundamental concepts of psychoanalysis. Routledge. (Original work published 1973.)

Nancy, J-L. (1991). The inoperative community. University of Minnesota Press. (Original work published 1986.)

Nancy, J-L. (2000). Being singular plural. Stanford University Press. (Original work published 1996.)

Rancière, J. (2006). The politics of aesthetics. Continuum. (Original work published 2000.)

Rousseau, J-J. (1947). The social contract. Hafner Press. (Original work published 1762.)

Young, J. (2001). Heidegger's philosophy of art. Cambridge University Press. 